had good health and sight until twelve years ago, when a rash broke out, which she said lookedlike measles, over her body; she had also a sore-throat, which was so bad as to prevent her swallowing, but does not remember having had any pain or redness in the eyes. She soon after discovered muscæ in her left eye, which moved up and down like little specks of soot, and found also, when reading, that the letters appeared to be on one side. A short time after, a semi-transparent blue veil, about the size of a shilling, appeared in the left eye, which partially obscured her sight when she looked at anything, but was not sufficiently dense to preclude her reading moderate-sized type. The sight of this eye has lately become worse, so that now on looking straight forwards she can see nothing immediately in the axis of vision, but anything situated at the outer side she can see just well enough to recognise. The right eye was healthy until three weeks since, when she felt some slight shooting pains through it, but did not discover any diminution of sight until three days ago (Dec. 19th), when she found it so dim as to prevent her reading the newspaper. This patient says she has had several miscarriages during the last twelve years, but has three children living who are healthy. Before the sight of her left eye failed she used to notice flashes of fire when closing her eyes to sleep. Examination by ophthalmoscope. - Left eye: cornea, lens,
and humours clear; entrance of the optic nerve has a brownish, dull-yellow tint over it, vessels are distinct, though small. Towards the position of the yellow spot is a patch of rather larger size than the optic nerve, the ground of which resembles that of the optic nerve; but, in several parts, fragments of brown and black pigment are to be noticed; the margin also of this patch appears of a deep brownish-red. There are also some bright-red streaks running parallel to one another at the lower part. The rest of the bottom of the eye has a brownish-red-cast; the retinoid vessels appear distinct though smaller than in a healthy eye. - Right eye: humours clear; entranoe of the optic nerve much the same as the left; the bottom of the eye appears of a brownish calour, but is streaked with white, and immediately over the position of the yellow spot itself, is a dark spot, nearly covering it. Below the horizon, the bottom of the eye has a dull, brownish-red cast; the retinoid vessels are small, but perfectly distinct, as in the left eye.

Dec. 30th, 1856. - She can read large print with the right eye if she looks down with the left eye; but says that when look. ing for a moment or two, a spot, the size of a threepenny piece, appears to come over the sight at the part she is looking at, which does not however entirely obscure the type, but renders it indistinct. States that she was subject to bleeding at the nose when she was suckling; and that when she menstruated, the bleeding was more severe. The epistaxis has ceased about twelve months. Bichloride of mercury and the decoction of cinchona bark mixture was prescribed for her. This she continued until January $16 \mathrm{th}, 1857$, when, a slight diarrhoea setting in, this was changed for small doses of mercury with chalk and rhubarb, every alternate night, and compound rhubarb mixture twice a day.

Feb. 2nd, 1857.--Improving; examined by ophthalmoscope; the black spot is not quite so large, but a very large quantity of pigment still obseures the retinal vessels in the left eye; the right is improving.

9th.-Examined by ophthalmoscope; right eye still improving; can see better; left optic nerve much clearer, and feel better if it were more natural." Ordered, compound iron mixture, one ounce, twice a day.

25th. - Improving in sight and general health. Since returaed to the country much improved.

CASE.-Musca Volitantes.-E. K- , female, aged fifty, admitted as an out-patient June 29,1855 . A delicate-looking person; pulse small, 60 ; has always had weak sight, and on several occasions, inflammation of the eyes; general health she considers to be good; married, and has several children. In 1853 her eyes became dim, and since then she has had a film floating about in the right eye; the dimness continued to increase up to the present time, and now vision is almost gone. The left eye is not yet in so bad a state, and sufficient vision remains to enable her to see her way about.

Examined by ophthalmoscope. - In the right eye masses of greyish streaks are floating about, the retinal vessels congested, irregular, and not well-detined; the capsule of the lens slightly thickened, especially at its periphery; the left eye is less congested, and apparently without floating masses. . Ordered a tonic mixture, containing soda, rhubarb, and infusion of quassia, with occasional and small doses of mercury pill. In a few weeks she was able to distinguish objects more clearly, and under a continuance of this treatment, the sight improved in the left eye; with the right eye she was able to read tolerably-sized print. The muscæ, or grey masses, became much less apparent, and in two months she left the hospital believing herself cured.

CASE.-A. B - aged twenty-nine, law clerk, applied June 29,1855 , with congestion of the retina of left eye. A thin, tall, light-complexioned, nervous man. Described the complaint as having, during several months, given him much, annoyance. At that time he could not see to read or write with it; general health tolerably good, but frequently suffering from bilious attacks. The iris of left eye slightly differs in colour; the lens, which appeared opaque by daylight, upon examination with the ophthalmoscope, was found not to be so, this colour evidently being due to congestion behind the lens; the vessels of the retina very irregular, and so much congested as to nearly conceal the entrance of the optic nerve; patches of serous effusion were seen between the choroid and retina; this eye only sensible to light at the inferior and internal portions. Mercurial pill, with aperient draughts, were ordered daily, under which treatment he much improved; tonics were then prescribed for a fortnight, and at the end of a month he was able to resume his occupation.

This case is valuable as showing the use of the ophthal. moscope, not only in deciding the question of opacity of the lens, but enabling us at once to direct attention to the seat of disease. Hence the treatment became most efficient. I have lately seen this patient, and he tells me he has had no return of the affection; but has been carefully following the advice given as regards resting the eyes as much as possible, and attending to his general health.

CASE. - R. R_, aged fifty-three, a cook, applied on 20th July, 1855. She states that her sight began to fail about two years ago, but has been able to do needlework until very recently; suffers from headaches and bilious attacks, which always increase the dulness of sight. General health, though not very good, has always permitted her to perform her daily work. Catamenia ceased ten years since. She now has a web over the right eye, which increases in size at night, and is accompanied by pain over the brow and head.

Examined by the ophthalmoscope.-The retinoid vessels much congested; a thick red web obscures the optic nerve. Left eye less congested than the right, and sight better in it; she indeed depends upon it for the small amount of useful vision remaining. A few grey striæ float about in the vitreous; lens quite clear.

Ordered a powder every night containing eight grains of calomel with five grains of Dover's powder, followed by an aperient draught every morning. Cantharides plaster to the neck. The effect of the mercury was kept up by a mixture of biniodide of mercury in decoction of bark; and at the end of two months she left the hospital, very much improved.

(To be continued.)

\section{EXPERIMENTS ON ARTIFICIAL DIGESTION.}

By THOS. K. CHAMBERS, M.D., F.R.C.P., LECTURER ON THE PRACIICE OF MEDTCINE AND PHYSICLAN TO ST. MARY'S HOSPITAL.

THE following experiments seem to exhibit pretty clearly the power of dissolving coagulated albumen possessed by different reagents employed for that purpose in artificial digestion. Pieces of hard-boiled white of egg were carefully wiped and weighed, and suspended without motion for twenty-four hours in beakers containing the solvent to be tested, mixed with about two ounces of water, and kept in a water oven at an even temperature. This of course does not exhibit a fair picture of the action of such reagents in the stomach, where the constant rolling movements, and the wiping away immediately of each successive portion dissolved by the copious stream of gastric juice, offer such favourable conditions. But it is a better comparative test than if the motion and stream are imitated artificially, as the attempt to do this acts un. equally on different specimens. I should advise all persons purchasing pepsine thus to estimate the value of the articles offered them. 


\begin{tabular}{|c|c|c|c|c|c|c|}
\hline - & & $\begin{array}{c}\text { Temperature. } \\
\text { Fahr. }\end{array}$ & $\begin{array}{l}\text { Weight } \\
\text { of Albumen } \\
\text { tested. }\end{array}$ & $\begin{array}{l}\text { Weight } \\
\text { after } \\
24 \text { hours. }\end{array}$ & $\begin{array}{c}\text { Loss } \\
\text { per Cent. }\end{array}$ & REMARKS. \\
\hline I. & $\begin{array}{l}\text { Ten grains of a powder prepared by Godfrey } \\
\text { and Cooke with gastric-juice dried upon } \\
\text { starch, mixed with lactic acid, (in imitita- } \\
\text { tion of M. Boudault's " Poudre Nutri- } \\
\text { mentive," No. 1,) with } 3 \text { grains of hypo- } \\
\text { sulphite of soda. }\end{array}$ & $\stackrel{\circ}{100}$ & $\begin{array}{l}\text { Grains. } \\
39 \cdot 0\end{array}$ & $27 \cdot 2$ & $30 \cdot 2$ & $\begin{array}{l}\text { The remaining mass } \\
\text { of white of egg was } \\
\text { much cracked and } \\
\text { very friable, so that } \\
\text { some a ccidental } \\
\text { loss is possible. }\end{array}$ \\
\hline II. & $\begin{array}{l}\text { Ten grains of Boudault's own " Poudre } \\
\text { Nutrimentive," No. 1. }\end{array}$ & 98 to 104 & $42 \cdot 2$ & $31 \cdot 2$ & $26 \cdot 0$ & Sweet. \\
\hline III. & $\begin{array}{l}\text { Ten grains of the above-named imitation of } \\
\text { Boudault's "Poudre Nutrimentive," No. } 1 .\end{array}$ & 98 to 104 & $42 \cdot 0$ & $31 \cdot 3$ & $25 \cdot 5$ & Sweet. \\
\hline IV. & $\begin{array}{l}\text { Fifteen grains of Boudault's "Poudre Nutri- } \\
\text { mentive," No. 1., some old cheese chewed, } \\
\text { and a few drops of hydrochloric acid. }\end{array}$ & 90 & $13 \cdot 3$ & $10 \cdot 1$ & $24 \cdot 0$ & Sweet. \\
\hline V. & $\begin{array}{l}\text { Ten grains of Boudault's "Poudre Nutri- } \\
\text { mentive," No. l. }\end{array}$ & 98 to 104 & $30 \cdot 8$ & $23 \cdot 7$ & $23 \cdot 0$ & Sweet. \\
\hline VI. & $\begin{array}{llllll}\text { Fifteen grains of ditto } & \ldots & \ldots & \ldots & \ldots & \ldots\end{array}$ & 90 & $7 \cdot 2$ & $5 \cdot 7$ & $20 \cdot 8$ & Sweet. \\
\hline VII. & $\begin{array}{l}\text { Ten grains of Godfrey and Cooke's imitation } \\
\text { of ditto. }\end{array}$ & 104 & $34 \cdot 8$ & 27.8 & $20 \cdot 1$ & Sweet. \\
\hline VIII. & $\begin{array}{l}\text { Fifteen grains of Boudault's "Poudre Nutri- } \\
\text { mentive," No. 1, with half an ounce of } \\
\text { neutral saliva added to the water. }\end{array}$ & 90 & $14 \cdot 7$ & $11 \cdot 1$ & $20 \cdot 0$ & $\begin{array}{l}\text { The solution had } \\
\text { become strongly } \\
\text { acid. }\end{array}$ \\
\hline IX. & $\begin{array}{l}\text { Ten grains of Godfrey and Cooke's imitation } \\
\text { of ditto, as in Experiment VII. }\end{array}$ & 104 & $35 \cdot 8$ & $28 \cdot 7$ & $19 \cdot 8$ & Sweet. \\
\hline $\mathrm{x}$. & $\begin{array}{l}\text { Ten grains of a more finely powdered imita- } \\
\text { tion of ditto, made by Savory and Moore. }\end{array}$ & ditto & $36 \cdot 2$ & $29 \cdot 2$ & $19 \cdot 3$ & Sweet. \\
\hline XI. & $\begin{array}{lllllllll}\text { The same } & \ldots & \ldots & \ldots & \ldots & \ldots & \ldots & \ldots & \ldots\end{array}$ & ditto & $38 \cdot 1$ & $31 \cdot 1$ & $18 \cdot 3$ & Sweet. \\
\hline XII. & $\begin{array}{l}\text { Fifteen grains of Boudault's " Poudre Nutri- } \\
\text { mentive," No. } 1 \text {, with a little saliva, not } \\
\text { enough to neutralize the lactic acid. }\end{array}$ & 50 & $16 \cdot 5$ & $13 \cdot 9$ & $15 \cdot 7$ & .. \\
\hline XIII. & $\begin{array}{l}\text { Old cheese chewed, and } 20 \text { drops of lactic- } \\
\text { acid solution. }\end{array}$ & 104 & $32 \cdot 3$ & $27 \cdot 8$ & $13 \cdot 9$ & Sweet. \\
\hline XIV. & $\begin{array}{l}\text { A teaspoonfi1l of "Tiquor Pepsiniæ," pre- } \\
\text { pared by Titterton, Birmingham. }\end{array}$ & 90 & $14 \cdot 9$ & $12 \cdot 9$ & $13 \cdot 4$ & Sweet. \\
\hline $\mathrm{XV}$. & $\begin{array}{l}\text { Four grains of dried and powdered gastric- } \\
\text { juice, prepared by Savory and Moore, quite } \\
\text { sweet and dry. }\end{array}$ & 98 to 104 & $34 \cdot 3$ & $29 \cdot 9$ & $12 \cdot 8$ & $\begin{array}{l}\text { It had become fotid, } \\
\text { but was atill acid. }\end{array}$ \\
\hline XVI. & $\begin{array}{l}\text { The same, with } 20 \text { drops of lactic-acid solu- } \\
\text { tion. }\end{array}$ & 104 & $34 \cdot 6$ & $31 \cdot 0$ & $10 \cdot 4$ & Sweet. \\
\hline XVII. & $\begin{array}{l}\text { Fifteen grains of Boudault's pepsin, saliva, } \\
\text { and } 2 \text { grains of sulphite of soda. }\end{array}$ & 98 to 104 & $14 \cdot 9$ & $13 \cdot 5$ & 9.3 & No smell. \\
\hline XVIII. & $\begin{array}{l}\text { Six grains of a soft, pasty, concentrated } \\
\text { gastric-juice, prepared by Savory and } \\
\text { Moore, with } 20 \text { drops of lactic-acid solution. }\end{array}$ & 104 & $36 \cdot 3$ & $33 \cdot 3$ & $8 \cdot 2$ & Sweet. \\
\hline XIX. & The same, without the lactic acid... $\ldots \quad \ldots$ & 98 to 104 & $42 \cdot 0$ & $39 \cdot 5$ & $5 \cdot 9$ & $\begin{array}{l}\text { Very foetid and } \\
\text { alkaline. }\end{array}$ \\
\hline $\mathrm{XX}$. & Twenty drops of lactic-acid solution $\quad \ldots \quad \ldots$ & 98 to 104 & $34 \cdot 3$ & $45 \cdot 5$ & + & $\begin{array}{c}\text { Much swelled and } \\
\text { soft. }\end{array}$ \\
\hline XXI. & $\begin{array}{l}\text { The piece of albumen digested in Experi- } \\
\text { ment IX. wiped, and put in old cheese and } \\
\text { lactic acid solution. }\end{array}$ & 60 & $26 \cdot 3$ & $27 \cdot 3$ & + & No apparent change. \\
\hline XXII. & $\begin{array}{l}\text { Boudault's " Poudre Nutrimentive," No. 1, } \\
15 \text { grains, with } 3 \text { grains of sulphite of } \\
\text { soda. }\end{array}$ & 50 & $17 \cdot 5$ & $17 \cdot 8$ & + & $\ldots$ \\
\hline XXIII. & $\begin{array}{l}\text { Titterton's liquor pepsiniæ, saliva, acidified } \\
\text { with hydrochloric acid, and no water. }\end{array}$ & 50 & $16 \cdot 4$ & $16 \cdot 7$ & + & $\ldots$ \\
\hline XXIV. & Hydrochloric acid and distilled water ... $\quad \ldots$ & 104 & $6 \cdot 0$ & $6 \cdot 5$ & + & $\begin{array}{l}\text { Softened and trans- } \\
\text { parent. }\end{array}$ \\
\hline $\mathrm{XXV}$ & $\begin{array}{l}\text { The gastric-juice as in Experiment XVIII, } \\
\text { syrup of figs, neutralized with liquor } \\
\text { potasse, and some loose pieces of albu- } \\
\text { maen. }\end{array}$ & 100 & $40 \cdot 6$ & $41 \cdot 9$ & + & $\begin{array}{l}\text { The mixture, from } \\
\text { being neutral, had } \\
\text { becomehighly acid, } \\
\text { from the formation } \\
\text { of lactic acid. }\end{array}$ \\
\hline
\end{tabular}


It will be observed that the experiments are placed in the order of the percentage which was dissolved of the albumen in each case. Some of them were made simply for the purpose of ascertaining which was the most reliable preparation of those commonly in use; others form part of a series illustrative of the function of digestion in health and disease, which I will take a future opportunity of using.

The results bearing on the present subject appear to be as follows :-

1. The most efficient mode of preserving the qualities of gastric juice is by separating the pepsine with lead and drying it on starch, as recommended by M. Boudault. (Compare the first nine experiments with the rest.)

2. The more exact the imitation of the process, the better. (Compare the first nine with Experiments X. and XI.)

3. A low temperature lessens the action even of the best (Exp. XII.), and utterly destroys that of the worst. (Exp. XXIII.)

4. Lactic acid alone has no digestive power. (Exp. XX.)

5. Even when generated during digestion from grape sugar it has no digestive power. (Exp. XXV.)

6. Hydrochloric acid alone has no digestive power. Exp. XXIV.)

7. Saliva impedes the solution of albumen in proportion as it neutralises the acids in the solvents. (Exp. VIII., XII., and XXIII.)

8. Hyposulphite of soda arrests decomposition, but not digestion. (Exp. I.) Sulphite of soda destroys weak and impedes strong digestion. (Exp. XVII., XXIII.)

On these grounds I have continued to employ Boudault's preparation, in spite of its high price. I have never found it fail in performing the duties demanded of it, except in cases quite unsuited to its exhibition. Those preparations which decompose, thongh they retain some solvent power, produce, as may be observed in the experiments, indigestion at the same time with digestion; that is to say, they canse chemical decomposition, unless arrested by the presence of acid.

That lactic acid should stimulate the action of a weak stomach is comprehensible enough; and probably in many cases it assists digestion by acidifying alkaline saliva or mucus swallowed; but solvent power it has none, and therefore can be of no service in the instances which are the true triumphs of pepsine,-viz., where the secretion of pepsine is annulled by disease.

\section{gy iflitrot}

OF THE PRACTICE OF

\section{MEDICINE AND SURGERY IN THE}

\section{HOSPITALS OF LONDON.}

Nulla est alia pro certo noscendi via, nisi quam plurimas et morborum et dissectionum historias, tam aliorum proprias, collectas habere et int secomparare.-Morgagni. De Sed. et Caus. Morb. lib. 14. Procmium.

\section{GUY'S HOSPITAL.}

MYELOID TUMOUR OF THE CONDYLES OF THE FEMUR, WITH NO ASSIGNABLE ORIGIN, IN A BOX, AGED FIFTEEN YEARS; AMPUTATION; RECOVERY.

(Uuder the care of Mr. HiLton.)

Is the earlier part of the present volume we recorded illustrations of many of the varieties of tumours, and amongst others the fibro-plastic, a good example of which was under Mr. Cock's care at Guy's, (see page 89.) On that occasion we particularly described the physical and histological characters of this form of heterologous growth. Amongst the latter, we mentioned the appearance in certain examples of the class of " mother cells, large oval bodies, enclosing from two to ten or twelve fibro-plastic nuclei. These cells are called myeloid by Paget, from their resemblance to cells found in the marrow of cetal bones, and the tumours in which they are formed he calls myeloid." (Drnitt's Surgery, p. 96, 7th edition.)

Now, at the present day it is of great importance to know everything about a myeloid tumour, because it is a matter 524 which enables us to estimate the prognosis of a case. The student will gain much information upon this subject in Mr. Paget's work on Tumours, but especially would we refer him to the 39th volume of the "Medico-Chirurgical Transactions," in which he will find a valuable paper on Myeloid and Myelocystic Tumours of Bone, by Mr. Henry Gray - a paper which at the same time particularly illustrates the case we record today, in which that form of growth involved the condyles of the femur, requiring amputation of the leg.

Those well versed in the pathology of tumours, of bone especially, are aware that it is almost impossible to distinguish between a hromatoid and medullary cancer affecting the osseous tissues and the true myeloid disease; and some years ago patients whose amputated limbs contained this last form of disease, which was then looked upon as cancer, not only recovered from the operation, but had no return of the disease. Such instances might at one time have been looked upon as local manifestations of cancer, actually cured by removal of the disease. Such is not the case, however.

What are the characteristics of myeloid tumours, as especially shown by Mr. Henry Gray's interesting researches? A growth very closely resembling malignant disease to the naked eye, but in reality not so; representing in structure a kind of overgrowth of sume of the normal constituents of bone, and originating probably from some local cause.

The essential elements consist in all cases of forms precisely similar to what is found in the marrow and other elements of bone in the fœetus, and at an early period of life; hence the name "myeloid" tumourg. In some instances their structure is so intermingled with cysts, that Mr. Gray very properly terms them "myelo-cystic" tumours in such cases. These tumours are for the most part limited in their development and growth to the osseous tissue, or its investing membranes, the periosteum and dura mater. They may occur in any bone; their growth is much less rapid than that of malignant disease, and the early period of life is chosen for their appearance. They are not malignant, and never return when once remosed; and lastly, they present a near relation with fibrous and fibrocystic tumours, and cartilaginous and osseous.

Besides the foregoing, there is another point of importance worth remembering. In true malignant disease of bone the shaft is extensively infiltrated with the particular affection itself; but in myeloid tumours the disease does not infiltrate the substance of the bone. In the nine cases given by $\mathrm{Mr}$, Gray the tumours took their origin in the epiphysal ends of the long bones; such was the case also in Mr. Hilton's patient. The ages varied from eighteen to thirty-six in Mr. Gray's cases, and in Mr. Paget's five cases the age was from fifteen to twenty-four. Early life, therefore, is favourable to their development; Mr. Hilton's boy was fifteen years old, and no cause was assignable for its appearance. There is no cachexia in myeloid disease, nor enlargement of the glands-points of importance in the diagnosis. But it is solely by microscopic examination that the true nature of the disease is determined, and, although perfectly innocent in character, amputation must be resorted to to remove it. The following abstract was kindly furnished us by Mr. T. Bryant, the late surgical registrar to the hospital:- -

Joseph S—, aged fifteen, a gas-fitter, residing at Walworth, admitted April 8th, 1857. He had always enjoyed good health till the end of December last, when, without any known cause, his left knee began to swell, unaccompanied with pain. The enlargement gradually increased, and stiffness of the jeint appeared, with some degree of pain on pressure. He continued, however, at his work till three weeks ago, when, by medical advice he applied blisters and took cod-liver oil. The growth became stationary. When admitted, he presented a delicate aspect, but his body was well nourished. In the situation of the condyles of the left femur, and extending upwards, there was a swelling of a firm, even, and tense character, which apparently consisted of dilated bone. The skin was free, and not discoloured, but very painful on applying pressure. The joint was movable, and evidently unaffected.

A few days after admission, the growth was puncturea, but blood only escaped. On the 28th of April the thigh was amputated above the middle, and the patient since that time has done well.

On examining the growth, its character became apparent. It had commenced in the lower part of the shaft of the femur, which it had expanded, some part of the shell of bone being now visible; it had encroached partially upon the epiphysis, which at the line of junction was slightly diseased; some new bone may be seen at the part where it is connected with the shaft. To the eye the tumour presented the usual features of 